\title{
Biometric Technologies: Application Possibilities At Airport for Passenger Processing
}

\author{
K O Gordyushova \\ ITMO University \\ St.Petersburg, Russia \\ kerry050696@gmail.com \\ E V Budrina \\ ITMO University \\ St.Petersburg, Russia \\ boudrina@mail.ru
}

\author{
L I Rogavichene \\ ITMO University \\ St.Petersburg, Russia \\ rogavichene@ list.ru
}

\author{
A S Lebedeva \\ ITMO University \\ St.Petersburg, Russia \\ hebo@rambler.ru
}

\begin{abstract}
This research focuses on the application of biometric technologies at the airport for passenger processing. In this study, analysis of the current technological processes at Pulkovo Airport is undertaken and methodologies are proposed to improve the current processes. Various factors are listed which can be eliminated by the introduction of biometric technologies at defined stages of passenger processing including entrance screening, check-in of passenger and baggage, customs, borders, and immigration inspections, pre-flight security inspections and boarding. Further, conclusions are drawn based on the analysis of the current process and processes after the introduction of biometric technologies.
\end{abstract}

Keywords: passengers, airport, process of passenger service, biometric technologies

\section{INTRODUCTION}

According to the estimates by the Ministry of Transport of the Russian Federation, by 2030 the volume of passenger traffic in Russia will be doubled, reaching 240 million people, therefore by 2030 an increase in airport congestion is expected. In 2018, Russian civil aviation reached a new record for the number of passengers, the numbers were estimated at around 116 million [1]. In connection with the growing passenger flow, one of the challenges for the aviation industry will be how to deal with the growing demand in the most efficient way and also at the same time avoiding or minimizing the reconstruction of airports and investments [2][3]. The solution to the problem of airport congestion is to improve and accelerate the technological operations of airports [3].

One solution to this problem can be biometric technologies that will not only accelerate the process of all pre-flight formalities but also increase the number of satisfied passengers, and at the same time increasing the level of security in such processes. Biometric technologies such as technologies used for identifying and confirming the person, based on the characteristics of biological, morphological and behavioral features. The main advantage of the use of biometric technologies in transport is to enhance transport security, they can also be used for: access control, video surveillance, fare collection, therefore, smoothening the flow of passenger traffic [4][5]. Using biometric data, the passengers, airlines, airports, and countries will be able to efficiently and safely manage passenger flow, and the process of processing passengers will be accelerated by a rate of twice the current amount. To implement biometric technologies at the airport, it is necessary to understand at what stages of the process the use of biometric technologies will enhance the flow of passengers.

\section{MATERIAL AND MeTHODS}

In this study, we analyze the current technological processes at Pulkovo Airport and proposed methodologies to improve the current process. Methodologies include:

1. Analysis of the current passenger traffic

2. Highlight the current technological stages of passenger service

3. Measure the time of passenger service at each stage

4. Identify the factors that hinder the flow at these stages

5. Identify the stages where the implementation of biometric technologies will reduce the time taken to complete pre-flight formalities and increase passenger safety. 


\section{RESULTS AND DISCUSSION}

\section{A. Capacity of Airport}

Pulkovo Airport is ranked fourth in Russia in terms of the number of passengers served annually. The infrastructure of Pulkovo Airport includes an airfield with two runways, a passenger terminal, a cargo terminal, a fueling complex, a parking complex, and other infrastructure facilities. The dynamics of passenger traffic at Pulkovo Airport for 20122018 is presented in Fig. 1 [6].

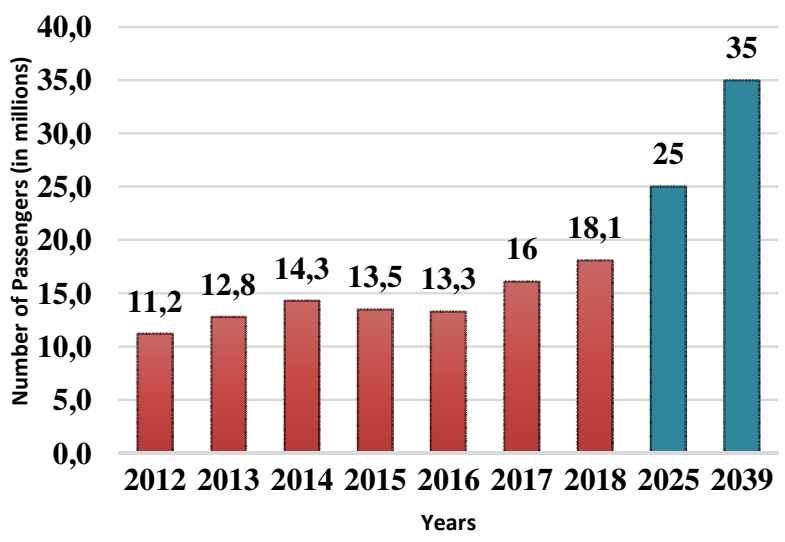

Fig. 1. The dynamics of passenger traffic at Pulkovo airport 2012-2018

Figure 1 states that, since 2016, there is a significant increase in the number of passengers at the airport. In 2018, the passenger flow amounted to 18.1 million passengers, which is equal to the maximum capacity of the airport. According to the forecast of Pulkovo Airport, the total passenger traffic in 2025 will reach 25 million passengers, and in 2039 it will be around 35 million passengers. This means that soon Pulkovo Airport will need a large-scale reconstruction since the number of passengers will exceed its maximum capacity if the processing of passengers is not improved. One suggested approach, to improve the throughput of the airport is the introduction of biometric technologies into the passenger service process. To optimally introduce biometric technologies, it is necessary to consider all the points of contact between the passenger and processing services during all stages of his processing. First, the technological stages of passenger service in the terminal are considered and the factors are identified which hinder the process of pre-flight formalities.

\section{B. Analysis of passengers processing in Airport Pulkovo}

In the course of the observations carried out in June 2019 at Pulkovo Airport, factors are identified for each passenger processing stage that causes in hinderance of processing of passengers and therefore increasing the time taken by the passenger to complete the pre-flight formalities. Such issues can be improved by introducing biometric technologies at these stages. The entire process of passenger service at Pulkovo Airport is divided into the following stages [1][7]:

1. Entrance screening
2. Check-In of passengers and baggage

3. Custom control

4. Border and immigration inspection

5. Pre-flight security inspection

6. Boarding

The entire technological process of passenger service is manually accompanied by airport personnel in every stage including passenger transportation, aviation security, federal customs service and the immigration service [8][9]. Next, the time taken at all stages by the technological processes are evaluated, along with the possibility of applying biometric technologies, where " + " means that biometrics can accelerate the process of passenger service, while "-" - no.

\section{1) Passenger entrance screening}

The initial inspection of passengers is carried out by the security of the airport. According to [10], the standard time for passing the passenger's entrance inspection is 0.3 minutes; a sample of 60 passengers was allocated as a study (Fig. 2).

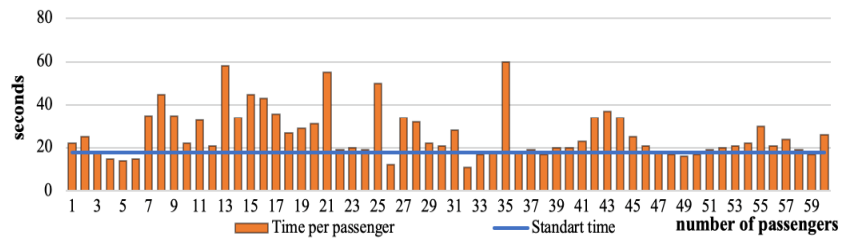

Fig. 2. Time taken by each passenger to pass the screening v/s the standard time

In the course of the measurements taken at the stage of the entrance screening, the following factors influenced the delay in screening as presented in Table I. The same also presents, the factors which can be eliminated or reduced with the application of biometric technologies.

TABLE I. FACTORS EFFECTING THE PROCESS OF PASSENGER ENTRANCE SCREENING

\begin{tabular}{|l|l|l|c|}
\hline \multicolumn{1}{|c|}{ Operation } & Num & \multicolumn{1}{|c|}{ Influencing Factors } & $\begin{array}{c}\text { Elimination } \\
\text { with } \\
\text { biometric }\end{array}$ \\
\hline $\begin{array}{l}\text { Baggage } \\
\text { Inspection }\end{array}$ & 1.1 & Oversized luggage & + \\
\cline { 2 - 4 } $\begin{array}{l}\text { Preparation to } \\
\text { go through the } \\
\text { metal detector }\end{array}$ & 2.1 & $\begin{array}{l}\text { Metal objects present in the } \\
\text { pocket of passengers }\end{array}$ & + \\
\hline $\begin{array}{l}\text { Passing the } \\
\text { through } \\
\text { metal detector } \\
\text { frame }\end{array}$ & 3.1 & $\begin{array}{l}\text { Activation of metal detector } \\
\text { in case of a metal object } \\
\text { present }\end{array}$ & + \\
\cline { 2 - 4 } & 3.2 & Searching of metal objects & + \\
\cline { 2 - 4 } & 3.3 & $\begin{array}{l}\text { Manual checking of } \\
\text { passenger }\end{array}$ & + \\
\hline $\begin{array}{l}\text { Screening } \\
\begin{array}{l}\text { Agent } \\
\text { Operations }\end{array}\end{array}$ & 4.1 & $\begin{array}{l}\text { Slower processing due to } \\
\text { manual interference }\end{array}$ & + \\
\hline
\end{tabular}

2) Check-in of passenger and baggage

Check-In of passengers at Pulkovo Airport begins hours before the departure and is carried out by the passenger 
transportation department [11]. Based on [10], the standard time for servicing one passenger should not exceed 90 seconds. In this study, a sample of 60 passengers are taken into consideration (Fig. 3).

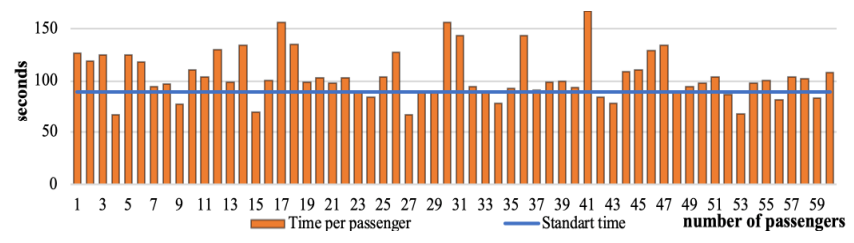

Fig. 3. Time taken by each passenger to check-in v/s the standard time

Factors affecting the process of check-in are highlighted in Table II [12].

TABLE II. FACTORS EFFECTING THE PROCESS OF CHECK-IN

\begin{tabular}{|c|c|c|c|}
\hline Operation & Num & Influencing Factors & $\begin{array}{l}\text { Elimination } \\
\text { with } \\
\text { biometric }\end{array}$ \\
\hline \multirow{2}{*}{\begin{tabular}{|l} 
Display \\
Passport
\end{tabular}} & 1.1 & Incorrect Check-In Desk & + \\
\hline & 1.2 & Searching for passport & + \\
\hline \multirow{3}{*}{$\begin{array}{l}\text { Passenger } \\
\text { search in DCS } \\
\text { system }\end{array}$} & 2.1 & Passenger absent from the system & - \\
\hline & 2.2 & \begin{tabular}{|l|l|} 
Incorrect search parameters in \\
Departure Control System
\end{tabular} & + \\
\hline & 2.3 & Ticket Issued on different document & + \\
\hline \multirow{2}{*}{$\begin{array}{l}\text { Passenger } \\
\text { Identification }\end{array}$} & 3.1 & Mismatch of document information & + \\
\hline & 3.2 & Data absent from the system & + \\
\hline \multirow{2}{*}{$\begin{array}{l}\text { Seat selection } \\
\text { in aircraft }\end{array}$} & 4.1 & $\begin{array}{l}\begin{array}{l}\text { Closure of seats due to centre of } \\
\text { gravity alignment }\end{array} \\
\end{array}$ & - \\
\hline & 4.2 & $\begin{array}{l}\text { Unavailability of seats for certain type } \\
\text { of passengers }\end{array}$ & - \\
\hline \multirow{4}{*}{$\begin{array}{l}\text { Check-in with } \\
\text { baggage }\end{array}$} & 5.1 & Clearance of oversized luggage & - \\
\hline & 5.2 & Clearance of oversized hand luggage & - \\
\hline & 5.3 & $\begin{array}{l}\text { Additional paperwork for payment of } \\
\text { oversized luggage }\end{array}$ & + \\
\hline & 5.4 & Airline clarification & + \\
\hline \multirow{3}{*}{$\begin{array}{l}\text { End-to-end } \\
\text { registration for } \\
\text { connecting } \\
\text { flights }\end{array}$} & 6.1 & $\begin{array}{l}\text { Missing Information regarding } \\
\text { connecting flight in the system }\end{array}$ & - \\
\hline & 6.2 & \begin{tabular}{|l}
$\begin{array}{l}\text { Entering a connecting flight } \\
\text { information in the system }\end{array}$ \\
\end{tabular} & + \\
\hline & 6.3 & $\begin{array}{l}\text { Baggage Check-In only for the first } \\
\text { flight not the subsequent flights }\end{array}$ & + \\
\hline \multirow{3}{*}{$\begin{array}{lr}\text { Print } & \text { luggage } \\
\text { tag } & \text { and } \\
\text { boarding pass }\end{array}$} & 7.1 & Printer failure (hardware limitations) & + \\
\hline & 7.2 & $\begin{array}{l}\text { Refilling boarding pass and luggage } \\
\text { tags into the printer }\end{array}$ & - \\
\hline & 7.3 & $\begin{array}{l}\text { Exhaustion of boarding pass and } \\
\text { luggage tags at desk }\end{array}$ & + \\
\hline \multirow{5}{*}{$\begin{array}{l}\text { Additional } \\
\text { services }\end{array}$} & 8.1 & Services not confirmed by airline & - \\
\hline & 8.2 & Upgrade of services & + \\
\hline & 8.3 & $\begin{array}{l}\text { Requesst for changing the seats in the } \\
\text { aircraft }\end{array}$ & + \\
\hline & 8.4 & $\begin{array}{l}\text { Check-In of pet animals and other } \\
\text { miscellaneous stuff }\end{array}$ & + \\
\hline & 8.5 & $\begin{array}{l}\text { Entering the loyalty card into the } \\
\text { system }\end{array}$ & + \\
\hline \multirow{3}{*}{$\begin{array}{l}\text { Check-In } \\
\text { Agent } \\
\text { Operations }\end{array}$} & 9.1 & $\begin{array}{l}\text { Lack of knowledge to handle } \\
\text { additional service requests from } \\
\text { passenger }\end{array}$ & + \\
\hline & 9.2 & $\begin{array}{l}\text { Slower processing due to manual } \\
\text { interference }\end{array}$ & + \\
\hline & 9.3 & Incorrect data entry & + \\
\hline
\end{tabular}

\section{3) Custom control}

Passing through customs control is only applicable in case of a declaration of custom duty to the airport customs service, therefore, it is decided not to consider this process as a factor which hinders the time taken to complete all technological processes.

\section{4) Border and immigration inspection}

Border and immigration control are carried out by the border control service [13][14]. According to [3], the standard time of service for one passenger should not exceed 90 seconds. During this study, a sample of 60 passengers are taken into consideration (Fig. 4).

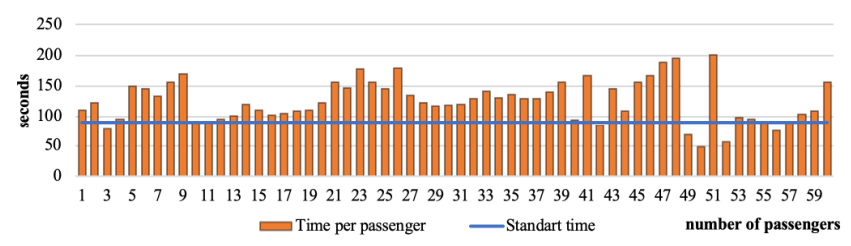

Fig. 4. Time taken by each passenger to pass through border and immigration inspection $\mathrm{v} / \mathrm{s}$ the standard time

Factors effecting the process of border and immigration inspections are highlighted in Table III [13].

TABLE III. FACTORS EFFECTING THE PROCESS OF BORDER AND IMMIGRATION INSPECTIONS

\begin{tabular}{|l|l|l|c|}
\hline \multicolumn{1}{|c|}{ Operation } & Num & \multicolumn{1}{|c|}{ Influencing Factors } & $\begin{array}{c}\text { Elimination } \\
\text { with } \\
\text { biometric }\end{array}$ \\
\hline $\begin{array}{l}\text { Display of } \\
\text { Passport }\end{array}$ & 1.1 & Covered passport & + \\
\hline $\begin{array}{l}\text { Fingerprint } \\
\text { scanning }\end{array}$ & 2.1 & System giving a false answer & - \\
\hline \multirow{2}{*}{$\begin{array}{l}\text { Passenger } \\
\text { restrictions }\end{array}$} & 3.1 & $\begin{array}{l}\text { Passenger visa does not comply with } \\
\text { crossing rules }\end{array}$ & - \\
\cline { 2 - 5 } & 3.2 & $\begin{array}{l}\text { Citizen exit restrictions due to } \\
\text { Conditions in [4] }\end{array}$ & - \\
\hline $\begin{array}{l}\text { Border control } \\
\text { agent operations }\end{array}$ & 3.1 & $\begin{array}{l}\text { Slower processing due to manual } \\
\text { interference }\end{array}$ & + \\
\cline { 2 - 5 } & 3.2 & Unable to identify passenger & + \\
\hline
\end{tabular}

\section{5) Pre-flight security inspection}

Pre-flight screening of passengers is carried out by the aviation security service. Based on [11], the standard time for passing the passenger's entrance inspection is 30 seconds. During this study, a sample of 60 passengers is taken into consideration (Fig. 5).

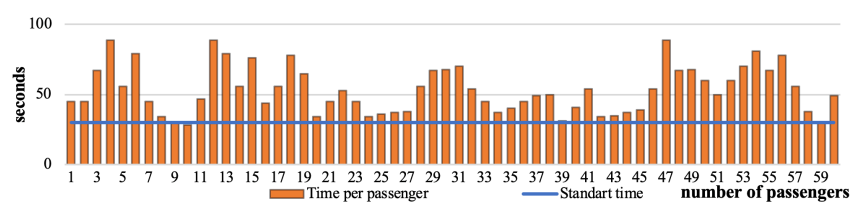

Fig. 5. Time taken by each passenger to complete pre-flight security inspection $\mathrm{v} / \mathrm{s}$ the standard time

Factors effecting the process of pre-flight security inspections are highlighted in Table IV [15]. 
TABLE IV. FACTORS EFFECTING THE PRE-FLIGHT SECURITY INSPECTIONS

\begin{tabular}{|l|l|l|c|}
\hline \multicolumn{1}{|c|}{ Operation } & Num & \multicolumn{1}{|c|}{ Influencing Factors } & $\begin{array}{c}\text { Elimination } \\
\text { with } \\
\text { biometric }\end{array}$ \\
\hline $\begin{array}{l}\text { Inspection of } \\
\text { hand luggage }\end{array}$ & 1.1 & Presence of electronics in hand luggage & + \\
\hline $\begin{array}{l}\text { Preparation to } \\
\text { go through the } \\
\text { metal detector }\end{array}$ & 2.1 & $\begin{array}{l}\text { Presence of metal objects on the } \\
\text { passenger }\end{array}$ & - \\
\hline $\begin{array}{l}\text { Inspection of additional clothes present } \\
\text { on the passenger } \\
\text { the metal } \\
\text { detector frame }\end{array}$ & 3.2 & $\begin{array}{l}\text { Activation of metal detector in case of a } \\
\text { metal object present }\end{array}$ & + \\
\cline { 2 - 5 } & 3.3 & Searching of metal objects & - \\
\hline $\begin{array}{l}\text { Screening Agent } \\
\text { Operations }\end{array}$ & 4.1 & $\begin{array}{l}\text { Slower processing due to manual } \\
\text { interference }\end{array}$ & + \\
\hline
\end{tabular}

\section{6) Boarding}

Passengers are boarded by the passenger transportation service. Based on [11], the standard time for passing the landing stage is 5 seconds. During this study, a sample of 60 passengers is taken into consideration (Fig. 6).

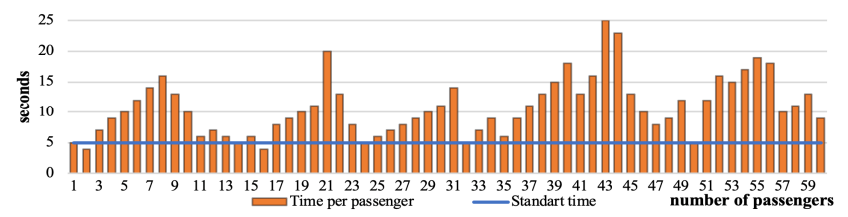

Fig. 6. Time taken by each passenger to board v/s the standard time

Factors effecting the process of boarding are highlighted in Table V.

TABLE V. FACTORS EFFECTING THE BOARDING

\begin{tabular}{|l|l|l|c|}
\hline \multicolumn{1}{|c|}{ Operation } & Num & \multicolumn{1}{|c|}{ Influencing Factors } & $\begin{array}{c}\text { Eliminati } \\
\text { on with } \\
\text { biometric }\end{array}$ \\
\hline $\begin{array}{l}\text { 1. Display of } \\
\text { Passport }\end{array}$ & 1.1 & Incorrect gate for passenger & + \\
\hline $\begin{array}{l}\text { 2. Passenger } \\
\text { Identification }\end{array}$ & 2.1 & $\begin{array}{l}\text { Searching for passport and boarding pass } \\
\text { Data mismatch on passport and boarding } \\
\text { pass }\end{array}$ & + \\
\hline $\begin{array}{l}\text { 3. Scanning and } \\
\text { Confirming the } \\
\text { Boarding }\end{array}$ & 3.1 & Issues with scanning & + \\
\hline $\begin{array}{l}\text { Limitations of the registration system } \\
\text { (delayed system response or failure) }\end{array}$ & + \\
$\begin{array}{l}\text { 4. Operations of } \\
\text { the passenger } \\
\text { service agent }\end{array}$ & 4.1 & $\begin{array}{l}\text { Lack of knowledge to handle additional } \\
\text { service requests from passenger }\end{array}$ & + \\
\cline { 2 - 4 } $\begin{array}{l}\text { Slower processing due to manual } \\
\text { interference }\end{array}$ & + \\
\hline
\end{tabular}

\section{CONCLUSION}

Thus, Pulkovo Airport is not ready to increase passenger flow as at all stages of the technological process, delay of passenger processing is detected. The identified factors most pronouncedly affect the service time of passenger flows at Pulkovo Airport. All these factors are related to the recruitment of new personnel, staff turnover, restrictions on passenger service systems, passenger identification by passport, lack of passenger data in the systems, improper allocation of airport resources, etc. Therefore, the acceleration of passenger service and increase throughput is possible by introducing biometric technologies at mentioned stages that will help to avoid future crises in the airport with minimal change in infrastructure.

\section{References}

[1] Transport strategy of the Russian Federation until 2030 - Moscow, 2008.

[2] IATA passenger forecast, January 2018 [Electronic resource]. Available at: http://airlines.iata.org/sites/default/files/Data\%20 spread\%20dec-jan\%20v5.pdf (Accessed: 20.11.2019).

[3] USD1 trillion for airport construction globally - but it's not enough [Electronic resource]. Available at: https://centreforaviation.com/ analysis/reports/usd1-trillion-for-airport-constructionglobally---but-itsnot-enough-capa-database-356495 (Accessed: 20.11.2019).

[4] SITA Passengers in Focus [Electronic resource]. Available at: https://www.sita.aero/globalassets/docs/infographics/passengers-infocus-infographic.pdf (Accessed: 28.11.2019).

[5] NEC's Video Face Recognition Technology Ranks First in NIST Testing [Electronic resource]. Available at: https://www.nec.com/ en/press/201703/global_20170316_01.html (Accessed: 20.11.2019).

[6] Biometric self-service - taking the next steps [Electronic resource]. Available at: https://www.sita.aero/resources/blog/biometric-selfservice-taking-the-next-steps?utm_source=social\&utm_medium $=$ everyone-social\&utm_theme=it-insights\&utm_type=campaign (Accessed: 29.11.2019).

[7] Pulkovo Airport [Electronic resource]. Available at: http://www.pulkovoairport.ru (Accessed: 20.11.2019).

[8] T.V. Bogdanova and E.S. Oshchepkova, "Study of the influence of seasonality processes on the quality of passenger service by an airline at a departure airport", Vestn. University, State University, Section 11, pp. 83-89, 2015.

[9] The concept of passenger service at the new terminal at Pulkovo Airport, 64 p., 2013.

[10] V. Bogicevic, "The impact of traveler-focused airport technology on traveler satisfaction", Technol. Forecast. Soc., 2017 DOI: 10.1016/j.techfore.2017.03.038 (Accessed: 20.11.2019).

[11] "On approval of the Methodology and its application for calculating the technical feasibility of airports", Order of the Ministry of Transport of the Russian Federation of 24 February 2011, Section 63.

[12] “On Approval of the Federal Aviation Rules", General Rules for the Air Carriage of Passengers, Baggage, Cargo and Requirements for Serving Passengers, Consignors, Consignees, Order of the Ministry of Transport of the Russian Federation of 28 June 2007, Section 82.

[13] Job description of an agent in the passenger department of the Passenger Transportation Service at Pulkovo.

[14] Federal Law "On the Procedure for Departure from the Russian Federation and Entry into the Russian Federation", of 08.15.1996 Section 114 of Federal Law.

[15] "On State Border of the Russian Federation", Law of the Russian Federation of 1 April 1993, Section 4730-1.

[16] "On approval of the Rules for the pre-flight and after-flight inspection", Order of the Ministry of Transport of the Russian Federation of 25 July 2007, Section 104.

[17] Air Code of the Russian Federation of 19 March 1997, Section 60 of Federal Law.

[18] E. Nash, Facial Recognition to Replace Passports in Radical Security Overhaul at Australian Airports, 2017 [Electronic resource]. Available at: https://tottnews.com/2017/01/22/facialrecognition-australianairports/ (Accessed: 29.11.2019).

[19] "Will Biometric Smart Gates Become the Future of Airport Security?", Iritech, 2017 [Electronic resource]. Available at: http://www.iritech.com/blog/biometric-smart-gates-1116/ (Accessed: 25.11.2019). 